would supply materials for developing the story. I give this only as an illu-trationmany more might be adduced; but I cannot forbear from adding that Mr. Watson's book and the latest account published, I think, only last year of the state of Rome between Caesar and Nero might be indeed an answer to the supposed decay of Scholar- ship among us. But $I$ have said enough in the way of hint and suggestion--I do not profess to do more-and I will only conclude with what Horace has said:

Si quid novisti rectius istis, Candidus imperti; si non, his utere mecum.

\title{
LATIN ORTHOGRAPHY: AN APPEAL TO SCHOLARS.
}

Tine present marked divergencies of spelling in dictionaries and texts create a needless and very real difficulty to learners of Latin at all the early stages, and the undersigned, having been appointed by the Classical Association of England and Wales a Committee for the purpose of considering the spelling and printing of Latin texts for school and college use, are anxious to have the co-operation of all Latin scholars who are interested in the subject.

Their task, so far as the spelling of Latin words is concerned falls into two sections: to set forth, so far as known, the correct or preferable spellings in cases where there has been doubt or dispute, and to recommend these, where advisable, for general adoption in school and college texts.

In the absence of systematic works upon Latin orthography of a recent date investigators have to fall back upon separate articles and notes upon particular points in classical journals and commentaries which from the nature of the case may be easily overlooked. In addition to these sources which the Committee desire to utilise to the fullest possible extent, they believe that there must be a good deal of unpublished information which its possessors would be glad to see made available for the general good and which they are accordingly invited kindly to communicate to the Committee.

The Committee have drawn up a list of particular words exclusive of proper names which will be dealt with hereafter, the classical spelling of which seems to them to be still insufficiently determined. This list, which is printed below, contains in general only such words as do not fall under some general division of Latin orthography, for instance the assimilation or non-assimilation of prefixes in composition. And the Committee $n$ ould be very gratef ul to any scholar who will supply them with information respecting any of the words included therein.
This information may embrace anything that falls under the following heads: (1) the spelling of the word in good inscriptions belonging to the classical period, (2) the spelling in good manuscripts of classical authors who use the word, (3) references to periodicals, programmes, dissertations and commentaries where the spelling of the word is treated of.

In a matter of this kind it is necessary to fix upon some epoch as a starting point, and the Committee have selected as the most convenient one for this purpose the epoch of Quintilian, in so far as the spellings of that epoch can be ascertained.

They propose, at present, to excludo from consideration the spelling of all writers later than the second century A.D. or earlier than the first century B.c. Within these limits they propose to take accourt of all well attested variations.

Communications relating to the words in the list or to the general subject may be addressed to Professor J. P. Postante, 54 Bateman Street, Cambridge.

\section{First List of Latin Words of Doubtful ORTHOGRAPHY.}

From this list are omitted words, the classical spelling of which is admittedly fluctuating, and words in which an alternative, though current, spelling is known to be without good authority.

Words which may be found to have been improperly omitted will be added in a supplementary list.

$\begin{array}{ll}\text { absinthus } & \begin{array}{l}\text { bracchium } \\ \text { bybliopola, bybliotheca } \\ \text { absis }\end{array} \\ \text { acnua } & \text { caeremonia } \\ \text { baccar } & \text { caudez } \\ \text { balaena } & \text { caulis } \\ \text { ballista } & \text { clipeus }\end{array}$




coniunx
corulus
cottidie
cottona
crocodilus
crumina
de-and dis- in compounds
ee- in compounds in clas-
sical times
eiuro
elleborus
euhoe
exhedra
fascia
ferumen
filix
formidolosus
galbanatus, galbina

glutio, gluto, glutus

gorytus

hama

hibrida

hirnea

interimo and perimo

ligurio

magnopere and other compounds of opere miscellaneus

penna and derivatives percontor periurus

petorritum phaselus

pistris, pristis promunturium protenus, etc.

rames
recipero
religio
robigo
sanguinolentus
sarracum
scaena
scida
scrupulum
sepulcrum
setius

(Signed)

January 19, 1905. smaragdus

stellio, etc.

stillicidiun

tesca

trochlea

uaco

valetudo

uè- prefix

nehemens

R. S. Conway.

A. E. Housman.

W. H. D. Rouse.

J. P. Postante.

S. E. WIN BOLT.

\section{THE USE AND ORIGIN OF APOSTROPHE IN HOMER.}

Tre use of apostrophe as a feature of style in Homer does not seem to have met with much notice and, so far as $I$ am aware, has received as yet no adequate explanation. Geddes (Problem of the Homeric Poems, p. 36, n. 14) gives a list of the passages where apostrophe occurs and notes that Melanippus is the only 'Trojan honoured by the poet's personal address. Mure (Lit. of Greece, ii. 61) classes the usage among the 'elegant expedients' used by the poet ' to give a dramatic turn to the text.' But the 'expedient,' whether 'elegant' or not, must have had an origin.

Apostrophe of a particular hero occurs in all 19 times in the Iliad and 15 times in the Odyssey : the latter instances are all in the case of Eumaeus, the 'divine swineherd'; those in the Iliad are distributed as follows: Patroklos 8, Menelaos 7, Phoebus 2, Achilles 1, and Melanippus 1. Had the importance of the person or the poet's interest in him ( $v$. the Scholia quoted below) been the determining factor, the proportions would have been different. A classification according to the nature of the context yields some interesting results. found

A. Apostrophe of a particular hero is

(a) At an important crisis (i) for the hero a postrophized.

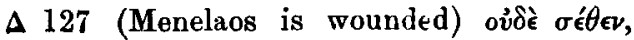

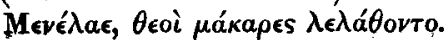

H 104 (Menelaos proposes to ansier Hek-

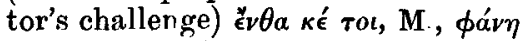

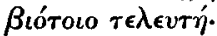

II 787 (Patroklos meets Apollo) ఢ้̈ $\theta^{\prime}$ ä $\rho a$

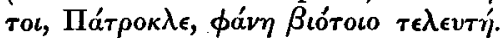

II 812 (Euphorbos attacks Patroklos) ơs to

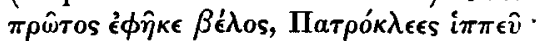
[for $\Pi 843$ s ee below (c)] ;

(ii) for some one else, N 603 (Peisandros attacks Menelans, driven by fate) $\sigma o e^{\text {, }}$

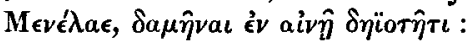

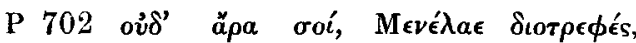

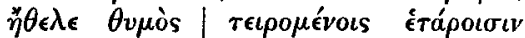
$\dot{a} \mu \nu v \epsilon \epsilon \in \boldsymbol{\epsilon}$.

(b) At the conclusion of a simile.

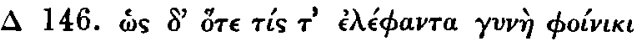

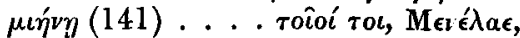

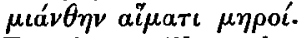

o 365 Phoebus fills the trench and destroys the wall ífía $\mu a ́ \lambda$ ', ¿́s ö $\tau \epsilon$

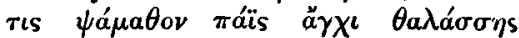

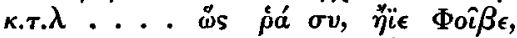

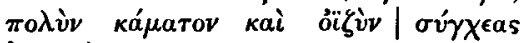
'A $\rho \gamma \epsilon i \omega \nu$.

O 582 Antilochos rushes upon Melanippos

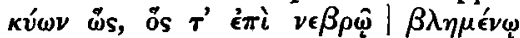

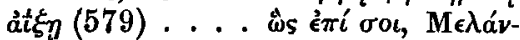

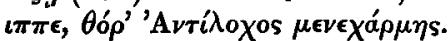

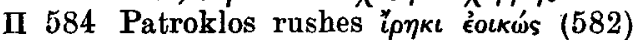

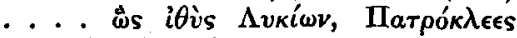

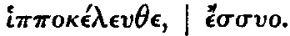

II 754 Pairoklos goes towards the body

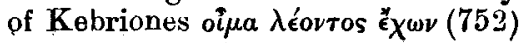

